\title{
DESCRIPTION OF LEXICAL SEMANTIC GROUPS OF EXPOUNDING SEMANTICS (ON THE MATERIAL OF THE UZBEK LANGUAGE WITH RUSSIAN EQUIVALENTS)
}

\author{
Muso Yuldashev \\ Samarkand state university, Samarkand, Uzbekistan \\ DOI: https://doi.org/10.31435/rsglobal_ijitss/28022019/6371
}

\section{ARTICLE INFO}

Received 11 December 2018

Accepted 17 February 2019

Published 28 February 2019

\section{KEYWORDS}

procedural, semantics, core, expounding predicate,

informative predicate, specific, intensification.

\begin{abstract}
This article deals with classification of expounding predicates in the Uzbek language. Analyzing the sources, 6 lexical-semantic groups of expounding predicates were defined. The most effective ones are informative predicates, we chose lexical-semantic predicates of the verbs "speak", "say" from them. Predicates included in this group have general lexical content of situation which locates in the core of the sentence. Predicates of this group have typological lexical meaning of messages and transmission of information about any situation. The construction of indirect speech is considered as informative predicates. Expounding predicates express why the situation wasn't a source, but a core of its reason.
\end{abstract}

Citation: Muso Yuldashev. (2019) Description of Lexical Semantic Groups of Expounding Semantics (on the Material of the Uzbek Language with Russian Equivalents). International Journal of Innovative Technologies in Social Science. 2(14). doi: 10.31435/rsglobal_ijitss/28022019/6371

Copyright: (C) 2019 Muso Yuldashev. This is an open-access article distributed under the terms of the Creative Commons Attribution License (CC BY). The use, distribution or reproduction in other forums is permitted, provided the original author(s) or licensor are credited and that the original publication in this journal is cited, in accordance with accepted academic practice. No use, distribution or reproduction is permitted which does not comply with these terms.

Introduction. Analyzing the lexical-semantic groups of expounding predicates and primarily the grammar of the modern Russian language, we have identified six groups as semantic types of predicates appearing in explanatory complex sentences with the conjunctions. However, the functional and semantic justification for this partitioning, distribution into subgroups, and many other issues of semantic interpretation, we carried out either independently or based on the cited literature of the question.

In this article, we analyze a subgroup of informative predicates "sау" демоқ "говорить" and “speak” айтмоқ "сказать".

Predicates of this group have a typical lexical meaning of the message, the transmission of information about any situation. If expounding predicates of other semantic groups can be expressed both by verbs and words of other parts of speech - adverbs, nouns, informative predicates are expressed only by verbs.

The content or subject of the message may be the fact of an event, knowledge of it, and not the event itself in its specific procedural form. This means that the dependent explanatory IC in the predicates of this group (as opposed to the predicates of a number of other groups) is exhausted only in the fact-forming value.

Another important semantic feature of all types of informative predicates in contrast to the predicates of the other groups is their correlation or synonymy with the constructions of direct speech. According to the real content, that is, at the reference level, the constructions of inline speech and IR are identical, compare: Келаман, - деди. - Я приеду, - сказал он. - "I will come", - he said. Келишини айтди. - Он сказал, что приедет. - He said that he would come (about his arrival). However, such phrases differ in their syntactic-grammatical meaning. 
Ёкутой гох хуарбий назоратга, гох итабга бориб Полвондан хат келмаганини, онаси, узли хавотирланаётганини айтарди. (J. Sharipov).

Ёкутой ходила и в военный комиссариат, и в штаб, говорили, что от Полвона нет писем, что его мать и сын волнуются.

Yokutay went to both the military commissariat and the headquarter, saying that there were no letters from Polvon, his mother and son were worried.

Билганимни айтаман, билмаганимни йўқ дейман. (J. Sharipov)

Про то, что я знаю - я расскажу, а чего я не знаю - скажу: нет, не знаю.

About what I know - I tell, and what I don't know - I say: no, I don't know.

Ундан ташқари мен доктор буллишни ууз командиримга, беш юзга яқин йигитлар олдида ваъда берганман. (Ғ. Ғулом).

Кроме того, я дал обещание стать доктором своему командиру, почти пятистам бойцам.

In addition, I made a promise to become a doctor to my commander facing to five hundred guys.

Сенга маълум ва равшан буилгайки, мангу худолар хохишингни маъқул кўрмадилар ва Яксартнинг ўнг сохилига уутсанг фалокатга учрашингдан башорат бердилар. (М.Осим)

Да будет тебе известно и ясно, что, если ты перейдёшь на правый берег Яксарта, попадёшь в беду.

The predicate of this subgroup denotes a message in the form of a speech expression, a statement of a situation or an event. This includes primarily verbs with a general (non-specific and non-intensifying) meaning of speech production: "speak-говорить", "sау-сказать", as well as a large group of verbs of intensifying or specific speech production. For example, in the verb "speakрассказать" the intensity lies in the fact that this speech action implies "to speak consistently about several or many events"; "forecast-предсказать" - involves efforts in anticipating the future, and so on. Specific speech actions "whisper-прошептать", "сry-кринуть" also includes intensity semas.

Within the semantic classification of verbs of speech, "specific" and "intensifying" verbs should constitute different classes, as they differ on such a semantic attribute: the first indicates the subject's physiological efforts in the production of the action itself, the second - on the subject's efforts to the addressee of the transmitted information with the purpose of developing one or another attitude to the message. Besides in the second case, the efforts of the subject of explanation are volitional, moral, intellectual, but not physiological, as in the first case. Within the framework of the functional (communicative) classification of the predicates of the expounding semantics of these verbs, it is possible to unite in one subgroup. Verbs of speech of a general nature (to talk, to say) in one of its meanings during transferring of the proverbs, sayings, opinions, and so on, in certain grammatical forms, are semantically transformed and transferred to the group of existential predicates. For example:

Шу тор йўлдан Аввонистонга хзам ўтса бўлади, дейишади.(К. Яшин).

Говорят, по этой узкой дороге можно пройти в Афганистан.

It is said that you can go along this narrow road to Afghanistan.

In such uses, the form "is said" (and similarly) does not indicate a message from any person, as it would be in phrases like: "he (I, you, we, and so on) says (I say ... and so on) that this road ... ". In the above given example, the word introduces information (that is, the predicate of the message) is absent altogether; it is compensated by the fact that such phrases are inserted into the direct speech of the first person. If the source of information is not the first person, then this can be given in a more complex structure: "he said that they say here that along this road ...". Exactly in similar cases, at first, tautological constructions shows the difference between the meanings of "communication of information" and "communication about the fact of existence of information".

In another of its meanings, verbs of speech can be synonymous with verbs of thought in contexts where the interlocutor is informed of the content of the subject's thoughts (practically, it is always the speaker, grammatically it is the first person of both numbers). In such cases, the verbs of speech have the meaning not "to informs the interlocutor with something in words", but the meaning "to speak to oneself, to formulate one's thoughts in words"; at the same time, the verbs of speech, as well as the verbs of thought, have the additional communicative meaning "to make public, to express one's thoughts out loud (but not: to anyone)":

Манава савилнинг ранги чаплашиб кетадими дейман. (О.Хусанов)

Я говорю (себе), а не поблекнет ли расцветка у этой проклятой штуковины.

I say (to myself), won't be faded the color of this damned thing. 


\section{REFERENCES}

1. Arutunov N.D. About the object of the general value. "Problems of linguistics." 1985. №3.

2. Vasilev L.M. The theory of semantic fields. "Problems of linguistics." 1971

3. Dictionary of linguistic terms. $5^{\text {th }}$ edition. "Piligrim" T.W. Zherebildo, 2010

4. Yuldashev M.M. Predicates of estimated characterizing semantics. Materials of the scientific conference. Samarkand-Shanghai, 2015, 27-29 Pp.

5. O.S.Akhmanova, Dictionary of linguistic terms, Moscow, 1969, pp.170-172

6. K.Yashin, Selected works, Tashkent, 1981

7. Sharipov J. 3-collection. Khorezm, Tashkent, 1982

8. Gafur Gulyam, Yodgor, Essays and stories, Tashkent, 1983

9. O.Husanov, Mysterious world, 1983 